Cahiers $d u$ MONDE RUSSE

\section{Cahiers du monde russe}

Russie - Empire russe - Union soviétique et États indépendants

$46 / 1-2 \mid 2005$

La Russie vers 1550

\title{
ОТ «ЗЕМЕЛЬ» К «ВЕЛИКИМ КНЯЖЕНИЯМ»
}

Andrej A. GORSKIJ

\section{(2) OpenEdition \\ Journals}

Édition électronique

URL : https://journals.openedition.org/monderusse/8781

DOI : 10.4000/monderusse. 8781

ISSN : $1777-5388$

Éditeur

Éditions de l'EHESS

Édition imprimée

Date de publication : 1 janvier 2005

Pagination : 83-90

ISBN : 2-7132-2055-6

ISSN : $1252-6576$

\section{Référence électronique}

Andrej A. GORSKIJ, « От «земель» к «великим княжениям» », Cahiers du monde russe [En ligne]

46/1-2 | 2005, mis en ligne le 01 janvier 2007, consulté le 02 septembre 2022. URL : http://

journals.openedition.org/monderusse/8781 ; DOI : https://doi.org/10.4000/monderusse.8781

Tous droits réservés 
chercher : repérer : avancer

Cet article est disponible en ligne à l'adresse :

http://www.cairn.info/article.php?ID REVUE=CMR\&ID NUMPUBLIE=CMR 461\&ID ARTICLE=CMR 4610083

\title{
От «земель» к «великим княжениям»
}

\author{
par Andrej A. GORSKIJ
}

| Editions de l'EHESS | Cahiers du monde russe

2005/1-2 - Vol 46

ISSN 1252-6576 | ISBN 2713220556 | pages 83 à 90

Pour citer cet article :

- A. GORSKIJ A., Cahiers du monde russe 2005/1-2, Vol 46, p. 83-90.

Distribution électronique Cairn pour les Editions de l'EHESS.

(C) Editions de l'EHESS. Tous droits réservés pour tous pays.

La reproduction ou représentation de cet article, notamment par photocopie, n'est autorisée que dans les limites des conditions générales d'utilisation du site ou, le cas échéant, des conditions générales de la licence souscrite par votre établissement. Toute autre reproduction ou représentation, en tout ou partie, sous quelque forme et de quelque manière que ce soit, est interdite sauf accord préalable et écrit de l'éditeur, en dehors des cas prévus par la législation en vigueur en France. Il est précisé que son stockage dans une base de données est également interdit. 


\title{
ОТ «ЗЕМЕЛЬ» \\ $\mathrm{K}$ «ВЕЛИКИМ КНЯЖЕНИЯМ»
}

\author{
О тенденциях политического развития \\ в Восточной Европе XIII-XV вв.
}

В XII столетии на Руси сложилась система политических образований, именуемых в источниках «землями». В большинстве земель (Волынской, Галицкой, Муромской, Пинской, Полоцкой, Рязанской, Смоленской, Суздальской, Черниговской) правили определенные ветви княжеского рода Рюриковичей: столы внутри каждой из этих земель распределялись между представителями соответствующей ветви. Исключение составляли: Киевское княжество - на киевский стол, сохранявший значение «старейшего» на всей Руси, могли претендовать князья разных ветвей; Переяславское (Переяславля-Русского) княжество - там в XII в. правили потомки Владимира Мономаха, но принадлежавшие к разным ветвям; Новгородская земля - здесь местное боярство присвоило себе право приглашать князей по своему усмотрению и ни одной из княжеских ветвей в Новгороде закрепиться не удалось. В начале XIII столетия, после прекращения местной ветви в Галицкой земле, объектом борьбы князей разных ветвей стал также Галич. Пределы «земель» были в XII - начале XIII в. относительно стабильны - во всяком случае, переходы стольных городов той или иной земли (кроме четырех названных выше, чей статус был особым) под власть князей «чужой» ветви были явлением 
исключительным (и кратковременным $)^{1}$. Княжеские усобицы были борьбой не за захват «чужих» земель, а либо за «общерусские» столы (Киев, Новгород, в XIII в. - Галич), либо за перераспределение княжений внутри земли (т.е. между князьями одной ветви) $)^{2}$.

Такие территориально-политические реалии существовали на Руси к моменту монгольского нашествия. Два с половиной века спустя, в конце XV столетия, после развала ордынского государства и ликвидации остатков зависимости русских земель от Орды, на восточнославянских территориях наблюдается совершенно иной политический пейзаж. Господствуют два крупных государственных образования: одно из них в исторической литературе принято именовать Великим княжеством Литовским (в источниках оно чаще всего фигурирует как «великое княжение Литовское и Русское»; при наличии неславянского территориального ядра примерно на 9/10 состояло из русских земель) и Великим княжеством Московским (в источниках, как правило, именуется «великим княжением» без территориального уточнения). В качестве рудиментов старой структуры сохраняются только две земли - Псковская (выделившаяся из Новгородской к XIV в.) и Рязанская (обе в сильной зависимости от Москвы).

Таким образом, в течение периода со второй половины XIII по конец $\mathrm{XV}$ в. в Восточной Европе произошел грандиозный территориальнополитический передел. Стабильность пределов «земель» сошла на нет, происходили масштабные присоединения владений одних политических образований другими, результатом чего стало в конце концов сохранение на политическом поле всего двух реальных игроков. Причем в основных чертах эта двухполюсная система сформировалась еще к концу XIV - началу XV столетия - уже тогда Великое княжество Литовское и Великое княжество Московское намного превосходили по могуществу другие политические образования (Тверское, Рязанское, Ярославское княжества, Новгородскую и Псковскую земли).

В историографии о присоединениях «чужих» территорий во второй половине XIII-XV вв. («примыслах», по тогдашней терминологии) написано немало, но крайне неравномерно. Лучше всего изучен рост владений московских князей (хотя и здесь есть свои пробелы - почти не исследовано приращение территорий вне Северо-Восточной Руси - «Суздальской земли») $)^{3}$. Получил освещение рост территории Великого княжества

1. Княжение во Владимире-Волынском князя из черниговской ветви Святослава Игоревича в 1206-1208 гг., предоставление черниговского стола Всеволодом Ольговичем Рюрику Ростиславичу (князю из смоленской ветви) в 1210-1212 гг. (в обмен на Киев), княжение смоленских князей в Полоцке с 1223 г. до начала 30-х гг.

2. См.: А. А. Горский, Русские земли в ХIII-XIV веках: Пути политического развития, М., 1996, с. 6-27.

3. См.: А. Е. Пресняков, Образование Великорусского государства, Пг., 1918; 
Литовского ${ }^{4}$. «Примыслы» же князей других политических образований фактически не изучались, хотя факты такого рода имели место.

Кроме того, рост владений Москвы и Литвы исследовался в рамках темы «централизации русских земель». В тени остались механизмы, способы присоединений. Их неизученность не позволила до сих пор даже поставить вопросы: почему вообще стало возможным овладевать территориями, подвластными другим княжеским династиям? Почему произошел «демонтаж» системы «земель», существовавшей в домонгольский период?

Учет всех случаев «примыслов» при должном внимании к их способам (там, разумеется, где их удается выявить по источникам) позволяет сделать ряд наблюдений, существенно меняющих традиционные представления, в первую очередь по поводу московской экспансии.

Во-первых, «примыслы» оказываются свойственны не только московским и литовским князьям. Присоединения «чужих» территорий осуществляли также князья рязанские и смоленские, а в пределах СевероВосточной Руси - переяславские (в качестве великих князей владимирских), ростовские, ярославские, суздальские и тверские. Во-вторых, в СевероВосточной Руси начало присоединениям «чужих» княжеств положила не Москва. Здесь, в «земле Суздальской», после Батыева нашествия сложилась политическая система, включавшая более десятка княжеств, управлявшихся разными ветвями потомков Всеволода Большое Гнездо, и «главное» княжество - великое Владимирское, стол в котором занимал по ханскому ярлыку правитель одного из «удельных» княжеств. В 70-90-е гг. ХІІІ в. фиксируется несколько случаев присоединения одних княжеств к другим. Происходило это с выморочными княжествами (Костромским и Углицким), и присоединение осуществлялось на основе либо права ближайшего родства, либо права великого князя владимирского (в случае с Угличем права родственников и великого князя столкнулись, что вызвало длительную борьбу за углицкое княжение) $)^{5}$. В 90-е гг. имела место попытка великого князя владимирского овладеть Переяславским княжеством, причем при наличии живого наследника переяславского стола ${ }^{6}$ В те же $90-$ гг. осуществился (по-видимому, по инициативе Орды) переход сильнейшего

М. К. Любавский, Формирование основной государственной территории великорусской народности: Заселение центра, Л., 1929; Л. В. Черепнин, Образование Русского централизованного государства в XIV-XV веках, М., 1960; В. А. Кучкин, Формирование государственной территории СевероВосточной Руси X-XIV вв., М., 1984.

4. См.: М. С. Грушевський, Історйя Украӥни - Руси, Київ, 1905, т. 2, 3; Ф. М. Шабульдо, Земли Юго-Западной Руси в составе Великого княжества Литовского, Киев, 1987; О. Русіна, Україна під татарами і Литвою, Київ, 1998.

5. См.: В. А. Кучкин, Формирование..., с. 104-124; А. А. Горский, «Политическая борьба на Руси в конце XIII века и отношения с Ордой», Отечественная история, 1996, с. 76-79.

6. См.: А. А. Горский, Москва и Орда, М., 2000, с. 24-27. 
княжества Черниговской земли - Брянского под власть смоленских князей 7 .

Московские «примыслы» берут начало с 1291 или 1300 г. ${ }^{8}$ Механизмы их были весьма разнообразны. Можно выделить одиннадцать способов. 1) Получение территории в качестве платы за поддержку одних князей (не из Северо-Восточной Руси) против других - Коломна (1300 г.), Калуга (кон. 60-х гг. XIV в.), возможно Можайск (ок. 1300 г.) и рязанские владения по pp. Протве и Луже (40-е гг. XIV в.) $)^{9}$;) наследование выморочного княжества по праву близкого родства - Переяславское (1302 г.). Нижегородское (ок. 1310 г. $)^{10}$; 3) получение по ярлыку с непосредственным присоединением половины или всей территории княжества - половина Ростовского (кон. 20-х или нач. 30-х гг. XIV в.), Дмитровское (30-е гг. XIV в.) и Муромское (1392 г. $)^{11}$ княжества; 4) «купля» (у местных князей) - Галицкое, Углицкое и Белозерское княжества (30-е гг. XIV в.), Мещера (70-е гг. XIV в.), массив рязанских владений на правобережье Оки (кон. 50-х или нач. 60-х гг. XV в.), Ярославское княжество $\left.(1463 \text { г. })^{12} ; 5\right)$ включение в состав великого княжества Владимирского (возглавляемого московским князем) выморочного княжества (с санкции Орды) - Юрьевское княжество (ок. 1347 г. $)^{13}$; 6) получение в Орде ярлыка на княжество с последующим превращением местных князей в служебных при оставлении за ними части территории - вторая половина княжества Ростовского (скорее всего, середина 60-х гг. XIV в.), Стародубское (вероятнее всего, середина 60-х гг. XIV в.), Нижегородско-Суздальское (1392 г.), Тарусское (1392 г.), Козельское (начало XV в.) ${ }^{14}$; 7) захват у Литвы (Ржевское княжество,

7. См.: А. А. Горский, «Брянское княжество в политической жизни Восточной Европы (конец XIII - начало XV в.)», Средневековая Русь, вып. 1, М., 1996, с. 7679; Он же, «Ногай и Русь», Тюркологический сборник, 2001; Золотая Орда и ее наследие, М., 2002, с. 149.

8. Датировка зависит от решения остающегося не вполне ясным вопроса, что было присоединено раньше - Коломна (1300 г.) или Можайск (1291 г. или первые годы XIV в.), см.: А. А. Горский, Москва и Орда, с. 18-20, 28-29; Он же, «Московские "примыслы" конца XIII-XV в. вне Северо-Восточной Руси», Средневековая Русь, вып. 5, М., 2004, с. 122-126, 134-138.

9. См.: В. А. Кучкин, «Русские княжества и земли перед Куликовской битвой», Куликовская битва, М., 1980, с. 50-51 (примеч. 135), 78; А. А. Горский, Москва и Орда, с. 18-20, 28-29, 70-72.

10. См.: В. А. Кучкин, Формирование..., с. 127-139, 209-211.

11. Там же, с. 264-282; А. А. Горский, Москва и Орда, с. 62-63, 123.

12. См.: В. Д. Назаров, «О включении Ярославского княжества в состав Российского централизованного государства», Россия в IX-XX веках: Проблемы истории, историографии и источниковедения, М., 1992; А. А. Горский, «Московские “примыслы” ...», с. 130-132, 170-175.

13. См.: А. А. Горский, Москва и Орда, с. 72-73.

14. См.: А. А. Горский, «Судьбы Нижегородского и Суздальского княжеств в конце XIV - середине XV в.», Средневековая Русь, вып. 4, М., 2004; Он же, «Московские “примыслы”...», с. 153-162; ПСРЛ, т. 15, вып. 1, Пг., 1922, стб. 74; т. 27, М.-Л., 1962, с. 243, 327. 
1368 г. $)^{15}$; 8) захват у Орды - Тула, «места татарские и мордовские» (70-е гг. XIV в.), Елец и «Меча» (70-е гг. XV в. $)^{16}$; 9) получение по ярлыку в наследственное владение - великое княжество Владимирское $(1383 \text { г. })^{17}$; 10) обмен с митрополитом (Алексин, нач. $90-$ х гг. XIV в.) ${ }^{18} ; 11$ ) силовое присоединение русских земель - Новгородская земля (1478 г.) и Тверское княжество $(1485 \text { г. })^{19}$.

В «примыслах» других русских князей прослеживаются следующие способы: 1) включение в состав великого княжества Владимирского выморочного княжества (с санкции Орды) - Костромское (1277 г.), Углицкое (нач. 90-х гг. ХІІІ в.), Переяславское (1305 г.), Нижегородское (1320 г.) княжества $\left.{ }^{20} ; 2\right)$ наследование выморочного княжества по праву близкого родства (с санкции Орды) - Углицкое княжество (80-е гг. XIII в., сначала отошло к ростовским, затем к ярославским князьям) ${ }^{21}$; 3) передача княжества Ордой при наличии мужских наследников - Брянское княжество (cеp. 90-х гг. ХІІІ в., передано смоленским князьям ${ }^{22}$; 4) выделение Ордой княжества из состава великого княжества Владимирского с передачей удельному князю - Нижегородское княжество в 1341 г. (пожаловано суздальскому князю) $)^{23}$; 5) восстановление самостоятельного княжества Ордой - Ростовское, Галицкое и Белозерское княжества в 1360-1362 гг., Нижегородское в 1408 г., середине $20-$ х и середине 40-х гг. XV в. ${ }^{24}$; 6) уступка по междукняжескому договору - Ржева в 1399 и 1448 г.

15. ПСРЛ, т. 15, вып. 1, стб. 87.

16. См.: А. А. Горский, «Московские “примыслы”...», с. 164-170.

17. См.: А. А. Горский, Москва и Орда, с. 117-118.

18. См.: В. А. Кучкин, Формирование..., с. 273-274.

19. См.: Л. В. Черепнин, Образование Русского централизованного государства..., с. 855-874, 887-895. Следует отметить, что московские князья нередко теряли присоединенные территории и их приходилось затем присоединять снова. Так было с Переяславлем (утерян в 1305 г., вновь присоединен вместе с великим княжеством Владимирским), Нижним Новгородом (с 1320 г. в составе великого княжества Владимирского, с 1341 по 1392 - столица Нижегородско-Суздальского княжества, в 1408-1414, середине 20-х и середине 40-х гг. XV в. временно уходил из-под московской власти), Галичем, Белоозером, Ростовом (выходили из-под московской власти в 1360-1362 гг.), Козельском (был под литовской властью с 1408 по начало 1430-х гг. и с 1448 по начало 90-х гг. XV в.), Ржевой (в 13721381 гг. в составе Литвы, в 1399-1401 - Тверского княжества, в 1448-1449 гг. ненадолго оказывалась под властью и Литвы, и Твери), Тулой (с 80-х гг. XIV в. вошла в состав Рязанского княжества, возвращена в середине XV в.) и «местами татарскими и мордовскими» (после 1382 г. вернулись под ордынскую власть, отошли вновь к Москве только после ликвидации зависимости от Орды).

20. См. примеч. $5,10$.

21. См.: А. А. Горский, Политическая борьба..., с. 76-79.

22. См. примеч. 7.

23. См.: В. А. Кучкин, Формирование..., с. 218.

24. ПСРЛ, т. 15, вып. 1, стб. 69-74; А. А. Горский, Судьбы Нижегородского и Суздальского княжеств... 
(передавалась ненадолго московскими князьями тверским $)^{25}$.

В отношении способов присоединений русских территорий литовскими князьями сведения источников более скудны. Можно отметить использование свойства в борьбе за выморочное княжество (Волынь, сер. XIV в.) и прямой силы - Северская часть Черниговской земли (60-е гг. XIV в.) и Смоленское княжество (кон. XIV - нач. XV в.) ${ }^{26}$. При этом переход под власть Литвы русских земель, обязанных ордынской данью, осуществлялся по договоренности литовских князей с Ордой ${ }^{27}$.

Таким образом, «примыслы» чужих территорий во второй половине XIII-XV вв. не были чертой исключительно московской и литовской политики. Это было явление, характерное для политического развития восточнославянских земель в «ордынский период» в целом. Спецификой московской экспансии было большое разнообразие способов и распространение примыслов за пределы Северо-Восточной Руси (на территории Рязанской, Смоленской и Черниговской земель). В свете традиционного представления об «агрессивности» московской политики может показаться неожиданным тот факт, что «примыслы» московскими князьями русских территорий до 1478 г. ни в одном случае не осуществлялись путем прямого силового захвата: силой отнимались только территории, принадлежавшие Литве и Орде, русские же города и волости присоединялись с использованием тех или иных «правовых», с точки зрения представлений того времени, оснований (в то время как в литовской политике, традиционно считающейся более «мягкой», силовой захват занимал заметное место).

Особо следует сказать о роли Орды в рассмотренных процессах. Прямые или косвенные данные об ордынской санкции имеются по поводу примерно половины «примыслов», но вероятно, что в реальности таких случаев было больше. При этом прямая инициатива Орды в изменении территориальнополитической структуры была редкостью (она вероятна при передаче Брянского княжества смоленским князьям в 90-е гг. ХІІІ в. и воссоздании Нижегородского княжества в 1341 г.). В большинстве случаев инициатива исходила от русских князей. Орда только поддерживала ее и пользовалась ею; поэтому говорить о намеренной ломке Ордой политической структуры

25. См.: В. А. Кучкин, «К изучению процесса централизации в Восточной Европе (Ржева и ее волости в XIV-XV вв.)», История СССР, 1984, № 6, с. 152-157. Остается неизвестным способ присоединения рязанскими князьями территорий Черниговской земли на левобережье средней Оки (конец XIII или начало XIV в.); неясно также, как осуществилась передача Тулы от Москвы к Рязани в 80-е гг. XIV в. - по воле Орды или по договоренности между московским и рязанским князьями.

26. См.: Ф. М. Шабульдо, соч., с. 24-25, 33-50; А. А. Горский, Русские земли..., с. 40-41; он же, Брянское княжество..., с. 90-91.

27. См.: О. Русіна, указ. соч., с. 58-61. 
на русских землях вряд ли было бы справедливо. Но само появление в середине XIII столетия центра верховной власти в Восточной Европе вне русских земель дало возможность такой ломки. Хан мог в принципе принять любое решение по поводу любого княжеского стола, оставалось только подыскать «правовое основание» для присвоения той или иной территории и добиться расположения ордынских правителей. Русские (и литовские) князья стали активно пользоваться этими возможностями.

В результате если в первой трети XIII в. намечалась тенденция к присоединению «общерусских», не закрепленных ни за одной княжеской ветвью столов (Киева, Новгорода, Галича) к соседним сильным землям (соответственно Черниговской, Суздальской и Волынской), то в «ордынский период» верх взяла другая тенденция: территориальнополитические перемены внутри земель и на их границах (вплоть до присоединения одних земель другими в целом). Лучше других использовали появившиеся возможности литовские и московские князья, в силу чего на карте Восточной Европы место десятка с лишним «земель» заняли два «великих княжения».

Российская Академия Наук

Институт российской истории

Gor-KS@yandex.ru 